\title{
The Mines Rescue Service in the Polish System of Crisis Management
}

\author{
Tomasz Ciupa ${ }^{1}$ \\ ${ }^{1}$ KWK ‘Bobrek’ Coal Mine, Węglokoks Kraj, Bytom - Poland
}

\begin{abstract}
The paper presents the place of the mines rescue service in the structures of the crisis management system in Poland. The mines rescue service as one of several entities of the rescue system in Poland focuses on helping injured miners and other people trapped underground. The paper mentions existing legal regulations concerning the mines rescue service and other emergency services. An important piece of legislation for members of mines rescue teams, is the ordinance of the Minister of Energy of 16 March 2017 which introduces a number of revolutionary changes such as obligation to deliver qualified first aid and on-thespot psychological support. In this way the mines rescue service has become more utilitarian and more universal and therefore may be efficiently used for operations in more general crisis situations and even better contribute to the smooth functioning of the state.
\end{abstract}

Index Terms - crisis management, the mine rescue service, the National System of Rescue and Firefighting.

\section{INTRODUCTION}

Despite ongoing discussions between practitioners and theoreticians in the field of security, there is no doubt that the primary legal act in the field of crisis management in Poland is the Act of 26 April 2007 on Crisis Management. The Act in its nature creates an integrated crisis management system, defining, inter alia, public administration entities as competent in these matters. The mines rescue service, which is the subject of these considerations, is not the leading unit of the National System of Rescue and Firefighting in Poland, and the general knowledge about mines rescuers is small, even among people dealing with the security issues. The research problem faced by the author of the present paper boils down to the following question: what role does the mines rescue service play in the Polish system of crisis management?

The need and frequency of rescue operations in Polish mining plants is decreasing, and the reason behind this is the declining number of mines in the country. However, the operations which have taken place in recent years demonstrated a demand for more specific and more advanced skills. It should be emphasized that the Polish mines rescue service, as well as the Polish mining industry in general, is struggling with numerous problems of financial, technical and organizational nature. Is the mine rescue service ready to meet modern security challenges? Is the work of mine rescuers only to participate in actions publicized by the media to reach miners trapped underground and to race against time clearing the rubble in order to find victims? Is the service prepared to undertake actions during more general mass-security threats e.g. a natural disaster? Can it be of assistance in case of a mass traffic accident? In order to provide answers to these questions one should have knowledge about the organisational structure of the service, about the level of training and skills of the rescuers, and about equipment at the disposal of the service. The author of the paper has conducted detailed research aimed at conceptual and terminological arrangement of the issues presented above.

\section{CRISIS MANAGEMENT}

The primary legal act which determines the authorities competent in matters of crisis management as well as their tasks and principles related to performance and financing of crisis management tasks, is the Act of 26 April 2007 on Crisis Management (amended, inter alia by the Act of 17 July 2009 amending the Act on Crisis Management). The Act creates an integrated crisis management system that includes: central and local government administration bodies, the armed forces of the Republic of Poland and selected private sector entities. The Act also explains the meaning of such concepts as: crisis management; crisis situation; critical infrastructure and civil planning (Katowice.uw.gov.pl, 2009).

According to the aforementioned law, crisis management is the activity of public administration bodies being an element of national security management. The activity includes: preventing crisis situations, preparing to take control in an emergency according to a detailed action plan, reacting in case

\author{
ASEJ - Scientific Journal of Bielsko-Biala School of \\ Finance and Law \\ Volume 22, No 3 (2018), 4 pages \\ DOI: $10.5604 / 01.3001 .0012 .7543$
}

Regular research paper: Published 30 October 2018

Corresponding author's e-mail: t1983c@gmail.com

Copyright (C) 2018 This is an open access article distributed under the Creative Commons Attribution CC-BY-NC 4.0 License.

Received: 4 September 2018; Accepted: 20 September 2018 
of crisis situations, removing consequences of a crisis/emergency and restoring resources and critical infrastructure. Bearing in mind the above, the following four stages of crisis management can be distinguished:

- crisis prevention phase aimed at eliminating or reducing the likelihood of crisis occurrence;

- preparation for the occurrence of a crisis situation, focusing on increasing the volume of forces and resources necessary for effective action (response) in a crisis situation;

- response phase, aimed at slowing down the development of a crisis situation, as well as reducing the damage caused during the crisis in progress;

- reconstruction phase aimed at stabilizing the situation and restitution to normality.

The aforementioned phases form the so-called crisis management cycle. It is worth noting that in the literature one can meet the fifth phase of crisis management called "learning" i.e. accumulating experiences gained during the development of an emergency situation and assimilating this knowledge, so that it can be used in the future. The presented cycle was built upon experiences of economic sciences, but it can also be successfully transposed to the field of ensuring general safety.

As regards the concept of a crisis situation, the Act of 2009 best reflects its essence and implements demands for central and local government, in particular with regard to facilitating the qualification of a given event as a crisis situation (Woiz.polsl.pl, 2009). The hitherto existing definition, contained in the Act of 2007 made the existence of this situation conditional on the threat which must have been caused jointly by the occurrence of three successive factors, namely:

- disruption or significant violation of social ties;

- serious disruption of the functioning of public institutions;

- application of necessary means to ensure or restore security to such a level that does not justify the necessity of introducing one of the emergency states referred to in article 228 paragraph 1 of the Constitution of the Republic of Poland (Woiz.polsl.pl, 2009).

However, the current approach sees a crisis situation only as the occurrence of a threat that adversely affects the level of human or environmental safety to a degree that limits the functioning of competent public administration authorities when the resources and procedures of these entities prove to be insufficient.

Civil planning plays an important role in crisis management. Civil planning should be understood as the entirety of organizational undertakings aimed at preparing public administration for crisis management, as well as planning support for the armed forces of the Republic of Poland in the event of their use and planning the use of the armed forces of the Republic of Poland to carry out tasks in the field of crisis management. Tasks in the field of civil planning include: preparation of crisis management plans, structures launched in crisis situations and resources necessary to perform tasks included in the crisis management plan.

The need to preserve the infrastructure necessary to ensure the functioning of society, in particular in the event of a crisis situation, plays a significant role in the modern world.
Following the experience of the United Kingdom, the United States, Estonia and Spain, the Act of 2009 puts special emphasis on the protection of critical infrastructure (Woiz.polsl.pl, 2009). The critical infrastructure includes the following systems: energy and fuel supply; telecommunications and IT networks; financial; food and water supply; health protection; transport and communication; rescue; ensuring the continuity of public administration; production, storage, storage and use of chemical and radioactive substances, including pipelines of dangerous substances.

\section{ORGANISATION OF THE MINES RESCUE SERVICE}

The mines rescue service in Poland has a long tradition, it is a constituent of the National System of Rescue and Firefighting, and it has a formal and systemic character. There are mutual relations and functions between individual mine rescue stations that operate in respective mining plants and the Central Mine Rescue Station. The forces and resources allocated to the system as needed are maintained in the ability to act. The mining rescue entities operate on the basis of the Mining Act and the State Medical Emergency Services Act, both acts have been linked together since 2017. The intended goal of the joint effort is providing smooth transition from the crisis situation to the normal state before the crisis.

The National System of Rescue and Firefighting aims to save the life and health of citizens, their property, to protect and rescue the environment during natural disasters, fires, floods etc. The system, in its assumption, brings together the units of the State Fire Service and other entities which, pursuant to the agreement, consented to participate in rescue operations. One of these services is the mines rescue which, as a part of the National System of Rescue and Firefighting, deals first and foremost with helping the miners who find themselves in a dangerous situation. The rescue operations performed by the mines rescuers include: counteracting threats, removing the effects of a catastrophy and restoring safe working conditions for miners. In addition, mines rescue teams are also involved in preventive and training activities.

The primary legal act that determines the organization of the mines rescue service in Poland is the Geological and Mining Act. The Act specifies the responsibility for the condition of the rescue service and obliges each mining plant to develop, maintain and update rescue plans. Pursuant to the Act, the mines rescue service consist of the in-house rescue units in respective mining plants and professional mines rescue service. Their tasks include: immediate assistance in the event of a threat to life or health of persons staying in a mine plant, provision of mine plant safety or general safety, counteracting all mining risks, carrying out preventive work defined in mining regulations, working towards improvement of safety for employees and minimizing hazards occurring in underground mine plants.

On the basis of the Geological and Mining Act of 16 March 2017, the Minister of Energy issued an ordinance on the mines rescue which clarified the organization of the mines rescue service in Poland. The changes covered the required age and 
length of professional experience of candidates applying for work in the mines service. In addition, from 1 July 2017, one member of each five-person-team must have completed a qualified first aid training course. Thus, the mines rescue regulations became consistent with the Act of 8 September 2006 on State Emergency Medical Services.

The basic mining rescue unit in Poland is the in-house mine plant rescue station. The in-house rescue team is an organizational unit of the mines rescue service which consists of:

- head of the mine plant rescue station;

- deputy head of the mine plant rescue station;

- mine rescuers;

- mechanics of rescue equipment.

Participation in the interventions of the rescue teams and membership in the mines rescue service is voluntary. The number of mines rescuers in a rescue team of an underground mining plant depends on the number of people staying underground within a day and is no less than: 15 mine rescuers - in the case of headcount of no more than 500 employees underground, the number increases up to 50 mine rescuers in the case of headcount of at least 501 employees and no more than 2000 employees underground. When the number of workers exceeds 2000 , the minimum number of rescuers rises to 80 . A rescue team as the smallest unit consists of: a patrol leader of the team and four mines rescuers, one of whom has been designated by the patrol leader as a deputy.

The entity that professionally deals with the mines rescue is the Central Mines Rescue Station in Bytom. The tasks to be performed by this entity are similar to the tasks set for the inhouse stations i.e. providing assistance to the injured employees in mine plants during technical failures caused by natural hazards and carrying out preventive work. The Central Mines Rescue Station is obliged to:

- ensure constant readiness of adequately qualified and equipped rescue teams and specialist mine rescue services;

- conduct cyclic exercises in the field of mine rescue;

- organize and conduct training courses in the field of mine rescue for candidates and rescuers;

- conduct consultations defining the state of preparation of mine plants for conducting rescue operations;

- regular organization of medical examinations for mine rescuers at a specialized medical examination center;

- conduct research and review rescue equipment;

- perform specialist chemical analyzes of air samples;

- calibrate gaseous reference materials;

- initiate, coordinate and conduct research works, conduct development and implementation activities ensuring technical and organizational progress in the mining rescue system.

The organizational structure of the Central Mines Rescue Station is based on three Regional Mines Rescue Stations in Bytom-Zabrze, Jaworzno and Wodzisław. The stations are kept in constant readiness to enable immediate departure whenever necessary (CSRG, 2017). The Central Mines Rescue Station also has a multi-tasking specialist emergency service with diverse characteristics, among which the following may be distinguished:

- measurement emergency service responsible for measuring physicochemical parameters of air and fire gases and for the assessment of gas mixtures explosiveness;

- emergency service for mine air inertization, used during underground fires;

- fire brigade, for carrying out rescue work during the fight against underground fires which require the use of equipment and devices for delivering firefighting foams and isolation of excavations, rock and goaf;

- technical and mines emergency service, to carry out rescue work related to the rescue of people trapped under the infarction or cut off from active workings due to a bump or a caving;

- water emergency service, to remove the effects of discharges or uncontrolled inflow of water into headings or water with loose material and to perform works using diving techniques;

- emergency rescue lifts, for evacuation of employees or for performing other rescue work in large diameter wells or boreholes as well as emergency, inspection works in shafts and large-diameter bores with the use of mechanical devices and mountaineering techniques.

\section{THE MINES RESCUE SERVICE IN OVERGROUND OPERATIONS}

At present, the Central Mines Rescue Station in Bytom is bound by an agreement of cooperation of 22 August 2013 with the Headquarters of the State Fire Service. The agreement defines the main principles of cooperation. An example of contribution of mines rescuers to the activities performed by the National System of Rescue and Firefighting can be the building disaster of 28 January 2006, during which the roof of the Katowice International Fair Centre collapsed under the pressure of snow and ice during a pigeon exhibition. Rescuers of the Regional Mines Rescue Station in Bytom and patrols of the Central Mines Rescue Station took part in the rescue operation. The experience of mines rescuers acquired during infarct actions in the grounded mining excavations proved to be vital while clearing the consequences of the disaster. 105 mines rescuers managed to recover 13 people trapped under the rubble and get 29 dead persons from under the metal sheet. The mines rescue services demonstrated remarkable commitment and determination during this particular intervention (Kuszewski and Bagiński, 2006). The mines rescue service also provided assistance on 16 May 2010 during floods, when the Kłodnica River crossed the alarm condition and threatened to pour out. Despite all the effort of various emergency services, the river unfortunately broke up along the Makoszowy district. Miners from the neighboring Coal Mine in Zabrze Makoszow and the rescuers of the Central Mine Rescue Station joined the rescue operation, providing men and equipment to pump out the water needed to conduct flood-related operations.

Another example of cooperation with the use of the specialist emergency service of the Central Mine Rescue Station was an 
accident in the opencast quarry mine in Smardzewice on 28 April 2011. During the blasting works, a mine worker had an accident while drilling the holes. The incident occurred in an excavation site flooded with water. The firefighters came to the site and searched for the missing worker on the surface of the basin. The next day, the emergency service of the Central Mine Rescue Station was called to the scene. The search for the missing employee was conducted in difficult conditions, the penetration took place in the absence of visibility and was threatened by landslides of neighboring rocks. With the help of a sound sonar, the divers brought the victim's body to the surface (Kubica and Krótki, 2011).

\section{THE INTERNATIONAL MINES RESCUE BODY}

The deaths of six mine rescuers in February 1998 to heat stress at the Niwka-Modrejow coal mine in southern Poland led to the birth of the International Mines Rescue Body. Determined to understand and prevent the tragedy from reoccurring, Polish mining officials hosted a conference in Bytom, near the site of the catastrophe, in May 2000 to discuss mine rescue procedures and research in harsh microclimates. At the conference, participants discussed the need for additional international cooperation on mine rescue issues and developed a proposal to establish an on-going international mine rescue organization. The aim of IMRB is to promote mine rescue at the international level and to improve mining rescue knowledge and good practices by supporting global cooperation (Minerescue.org, 2018). Every two years, IMRB co-organizes the industry championship - the International Mines Rescue Competition (IMRC) of rescue units from around the world, where the skills of mine rescuers develop in the space of a simulated rescue action. The event is a perfect opportunity to exchange experiences and knowledge. The rivalry between teams takes place in conditions similar to the natural working conditions of mine rescuers and the competitors have to deal with simulations of typical threats that are likely to occur in daily work in a pit. The panel of judges sets a number of challenges in which teams from various countries have an opportunity to demonstrate their skills. In the Canadian edition of the IMRC 2016 the challenges were:

- a simulated action underground;

- a first aid challenge;

- putting out an underground fire,

- a show of alpine skills;

- a knowledge test;

- a competition for equipment mechanics.

The latest IMRC 2018 was held in Russia where the competitors had to complete an obstacle course in virtual reality. The simulation took the form of a computer game in which the rescuers wore goggles and held controllers in their hands instead of real tools. It should be noted that Polish mines rescuers are among the world leaders in the competition, and each subsequent edition of the competition brings recognition to the Polish teams.

\section{CONCLUSIONS}

With over a century long tradition, the Polish mines rescue service is unquestionably one of the world's leaders. With an impressive technical base, it is constantly evolving and this progress is aimed both at improving the work comfort for the rescuers and improving the organization of the rescue operation in the mine plant. A milestone in the development of the Polish mine rescue service was the ordinance of the Minister of Energy of 16 March 2017. The changes introduced by the ordinance concerned the extension of rescuers' skills which now should include the ability to deliver qualified first aid and psychological support. According to the letter of the law, at least one of the mine rescuers performing their duties in a fivemember-group must possess the knowledge and skills referred to in the Act on State Medical Rescue. Previously binding legal regulations did not oblige mine rescuers to have knowledge and skills in the area of qualified first aid. Therefore, the value of the mine rescue patrol participating in medical rescue operations being an entity of the National Rescue and Firefighting System responsible for maintaining, saving, restoring or improving health, was increased. Bearing in mind the above, it can be stated with full certainty that both a wide range of mine rescuers' skills as well as specialized equipment that they can use can be used for operations in the event of mass and extraordinary events taking place outside the mine plants.

\section{REFERENCES}

CSRG. (2017). $O$ nas | CSRG. [online] Available at: http://www.csrg.bytom.pl/o-nas [Accessed 10 Jan. 2018].

Katowice.uw.gov.pl. (2009). Śląski Urząd Wojewódzki w Katowicach. [online] Available at: http://www.katowice.uw.gov.pl [Accessed 12 Feb. 2010].

Kubica, Z. and Krótki, J. (2011). Nurkowie w akcji. Ratownictwo Górnicze, 3(64), pp.17-23.

Kuszewski, A. and Bagiński, M. (2006). Katastrofa budowlana w hali wystawowej MTK - Katowice - Bytków 28.01.2016. Ratownictwo Górnicze, 1(41), pp.4-5.

Minerescue.org. (2018). IMRB : International Mines Rescue Body. [online] Available at: https://www.minerescue.org/purpose.htm [Accessed 11 Oct. 2018].

Woiz.polsl.pl. (2009). [online] Available at: http://www.woiz.polsl.pl/znwoiz/z87/Art_28_Socha.pdf [Accessed 10 Feb. 2010]. 